\title{
Сравнение транскриптомов двух генотипов растений Solanum phureja с контрастной устойчивостью к золотистой картофельной нематоде (Globodera rostochiensis)
}

\author{
А.А. Егорова*, Н.А. Шмаков, С.В. Герасимова, Г.В. Васильев, Н.В. Шацкая, \\ К.В. Стрыгина, Д.А. Афонников, А.В. Кочетов \\ ФИЦ Институт ичитологии и генетики СО РАН, Новосибирск, Россия \\ *e-mail: egorova@bionet.nsc.ru
}

Золотистая картофельная нематода (ЗКН) является паразитом корневой системы картофеля и некоторых других видов пасленовых. Нематоды образуют на корнях растений цисты, в которых развиваются их яйца. Больные растения характеризуются угнетенным ростом, преждевременным старением, почти не образуют клубни. Химические методы защиты являются неэффективными. Поэтому исследование генетических механизмов устойчивости картофеля к ЗКН является актуальной задачей.

В данной работе был проведен транскриптомный анализ двух образцов одного из подвидов картофеля - Solanum phureja, которые характеризуются контрастной устойчивостью к ЗКН. Один из них является чувствительным к нематоде, а другой высокоустойчивым, но в то же время не несет уже известных маркеров устойчивости. Мы предполагаем, что транскриптомный анализ этих двух генотипов позволит выявить гены, участвующие в механизме защитного ответа против ЗКН. Цель: Исследовать механизмы устойчивости растений Solanum phureja к золотистой картофельной нематоде Globodera rostochiensis.

Для транскриптомного анализа было решено взять образцы зараженных корней после 24 и 72 часов инокуляции, так как между этими временными точками наблюдается активное развитие гиперчувствительного ответа. Образцы были приготовлены нашими колегами из ВИР и ВИЗР согласно [1]. Были подготовлены образцы корней с трех растений каждого генотипа до заражения нематодой и после инокуляции с ней в течение 24 и 72 часов. Из них была выделена тотальная РНК и проведено секвенирование транскриптома на приборе Illumina NextSeq 500. Для оценки качества данных использовалась программа FastQC, фильтрация проводилась с помощью PrinSeq, картирование библиотек - с помощью STAR и TopHat, выявление дифференциально экспрессирующихся генов (ДЭГ) - с помощью EdgeR и DEGseq. Попарное сравнение транскриптомов исследуемых образцов выявило группы ДЭГ. Проводится анализ ДЭГ на предмет наличия функциональных взаимосвязей, выделение потенциальных генов устойчивости к ЗКН и реконструирование генных сетей.

Благодарности: Работа выполнена при финансовой поддержке гранта РНФ № 16-16-04073.

\section{Список литературь}

1. KochetovA.V. et al. (2017) Differential expression of NBS-LRR-encoding genes in the root transcriptomes of two Solanum phureja genotypes with contrasting resistance to Globodera rostochiensis. BMC Plant Biol. 17(Suppl 2):251. 